\title{
Crowdfunded Journalism: Innovation in Communication?
}

\author{
Lucas Vieira de Araújo
}




\title{
Crowdfunded Journalism: Innovation in Communication?
}

\author{
Lucas Vieira de Araújo ${ }^{1}$ \\ 1-Methodist University of São Paulo
}

\begin{abstract}
This work treats the innovation in journalism with the crowdfunding analysis as a premise. The justification for this research is a recent practice under construction and the lack of theory analysis of theories that could reach beyond the studies in communication. The innovation considered in this article is a practice built by various elements. Thus, we perform a multidisciplinary evaluation by using the contributions from communication, administration, machine technology philosophy and computing machine. To perform this, we make a bibliographic review and apply it to an exploratory research. Among the results achieved, we found out that the crowdfunding is an innovation under the different theoretical currents' points of view.
\end{abstract}

Index Terms - Journalism, Crowdfunding, Innovation

\section{INTRODUCTION}

I n the early $21^{\text {st }}$ century, when Castells (2000) [1] and other scholars dealt with network society, the consequences of the Internet advancement over the communication media and other matters related to the recent changes in human interactions, it is questioned what the future of journalism within this context will be. As it is an ongoing process, there are far more questions than answers. Many questionings concern the ubiquity, convergence and changes in hearing caused by new media (SERRA et al, 2015) [2]. Other authors discusses with more depth on the ways to produce, distribute and consume information from the integration of new scenarios and the media productions hybridity, as in the example of Canavilhas and Satuf (2015) [3].

The discussion regarding how to produce journalistic content in this new scenario of connected media with integration between media and users enjoying greater freedom of choice still presents various aspects that need further insight. One aspect revolves around the crowdfunded journalism. Even in countries like the United States where this practice is already more widespread, the ideas exchanges are still incipient, notably because they involve basic aspects of journalism, such as the costing of activity, the journalist ethics and the relationship of target groups with the communication media (KANEYA, 2015; ADLER, 2015) [4].

Article submitted on June 27, 2016. An agency of the Ministry of Education Capes (Personal Improvement Coordination) supported in part this work.

L. V. de Araújo is PhD student of the Methodist University of São Paulo and professor Assis Gurgacz College, Brazil (professorlucasaraujo@gmail.com).
For many crowdfunding enthusiasts, this would be an innovation due to the need of changes in journalism in face of the current reality (ADLER, 2015) [5]. In turn, innovating is still not part of many academic studies in the communication field, although there is considerable debate about the changes in vogue. Around a decade ago, Alves (2006) [6] regretted on the lack of innovative initiatives in the media and urged the digital journalism into changing its ways of operation. In this context, the aim of this article is to discuss innovation in journalism from the crowdfunding's point of view and the basic characteristics of the practice. To this end, we use a bibliographical research (GERHARDT, SILVEIRA, 2009) [7]. This type of study was classified by Santaella (2001, p. 43). 139) [8] as theoretical, whose "role is to fill gaps in knowledge, uncover and build conceptual reference frameworks".

In order to avoid a misjudge, the purpose of this work, the names and addresses of websites and other sources from the Internet will not be listed, which currently complies with the practice in Brazil and other countries in the world. We believe that the focus of crowdfunding in the analysis as a possible innovation for journalism turns the concern in mentioning addresses and names unnecessary. We must emphasize that the assessment for the act of innovating should take place based on the research in management, communication and technology fields, because they are guidelines for this article.

\section{THEORETICAL FRAMEWORK AND DiSCUSSION}

\section{A. Innovation}

Innovation is a recurrent term in many books, business manuals and news published by the press. Together with the term "entrepreneurship", innovation has become synonymous of what we understand as different from the current situation. However, authors such as Drucker (2003) [9] and Meira (2013) [10] evaluate the subject under a more technical and academic point of view, beyond cunning explanations. Drucker demystifies the common recurrent mentality, also present in the literature, that certain personal abilities and even a stroke of luck are enough for an individual considered as innovative. To the North American culture, the innovation usually requires typically entrepreneurial conduct, such as organization and planning.

Meira defines innovation with seven aspects, which represent the characteristics of innovation. According to Meira, innovation is purpose, conversation, change, social 
performance, power, synchronization and ideal awareness. The scope of definition for this term is so broad that the author summarizes innovation from what he calls the '3Is' (Impermanence, Imperfection and Incompleteness), which are "basic characteristics of all things" (2013, p. 300) [10], including the organizations. According to Meira's understanding, such aspects would be part of the innovation (p. 301) [10], because whoever does it, is someone "that suffers, by nature, from those three limitations".

Considered as the precursor of innovation studies, Schumpeter (1961) [11] introduced the concept of "creative destruction" to refer to the innovation process. He made an analysis from a historical perspective, which would indicate changes in the organization of production and the opening or closing of new markets. Those evidences, in turn, would be that capitalism changes the economic structure from within; that is, "unceasingly destroying the old and creating new elements" (1961, p. 110) [11]. As this process occurred within capitalism and in the long-term, the economist criticizes the superficial way some scholars use to assess the changes in the system, which would be misleading due to the focus on facts outside of a historical context.

Drucker endorses Schumpeter's statements concerning the premise that "the dynamic imbalance caused by the innovative entrepreneur, instead of balance and optimization, is the 'standard' for a healthy economy and the central reality for economic theory and practice" (2003, p. 35) [9]. Thus, Drucker asserts, the entrepreneurial behavior performs the work of changing the structures in vogue. "The entrepreneur is always looking for the change, reacts to it, and explores it as an opportunity" (2003, p. 36) [9].

Drucker also associates entrepreneurship and innovation because these would be "the specific instrument of the entrepreneurial spirit" (2003, p. 39) [9]. Hence, innovation would be the manner in which an entrepreneur carries out the task of interfering in the system. According to Drucker, "systematic innovation therefore consists in the purposeful and organized search for changes, and in the systematic analysis of the opportunities such changes might offer for economic or social innovation" (2003, p. 45) [9]. However, it is worth noting that Drucker does not see the innovation only under the technical and scientific point of view. On the contrary, to him, innovation "is an economic or social term, rather than technical" (2003, p. 43) [9], because changing can be of human level. Drucker brings the example of Japan, which would be an imitator and not innovative due to the fact it did not stand out by technical or scientific innovations in the field.

\section{B. Communication, Innovation and Technology}

Drucker's vision regarding social innovation corroborates with the studies on innovation and communication in Brazil. In one of the few works dedicated exclusively to the conceptual and deontological aspects of these two areas, Giacomini Filho and Santos (2008, p. 16) [12] affirm that the "Social Communication seems better suited to consider 'innovation' according to their effects, impacts, appropriation and social benefits". Such proposition endorses not only Drucker's statements (2003) [9], but also Wolton's affirmation (2010) [13] according to whom communication is characterized by the relationship that is established from the exchange of information among agents.

Approximations between innovation and communication, however, can move forward even further. One of those approximations is the fact that communication counts on appropriation mechanisms of technological changes in progress that can be performed not only under the cultural bias (GIACOMINI FILHO; SANTOS, 2008) [12] but also by the philosophy of technology, which correlates technology to the context, a basic aspect of the journalistic work. Vargas (1994) [14] points out that the term "technology" derives from the Greek word "techné", which makes reference to the body of knowledge and professional skills passed on from generation to generation in Ancient Greece. In the same way, "techné" comprised the technique of manufacturing machines or devices used daily by people.

Since then, Lima (2007) [15] states that a dichotomy was created around the conceptions of technique and technology, from epistemology to metaphysics. Lima mentions Mario Bunge when saying that it is necessary to differentiate technology from pure science because the former would be, for example, the human ability to manufacture tools, while the latter would seek for knowledge. Dusek (2006) [16] deepens those discussions by bringing three definitions for the term "technology". According to the author, "in order to turn an artifact or piece of instrumental into technology, it must be placed in the context of those who use, maintain and repair it" (2006, p. 50) [16].

This definition threatens the instrumentalist vision of technology and shows how essential the human factor is. Furthermore, Dusek's statement endorses other technology philosophy' scholars such as Vargas, to whom "the technique is originally a know-how which characterizes the presence of a human culture. (...) Man, doing and culture are aspects originating in human nature" (1994, p. 19) [14]. Vargas also argues that imbued with the instrumental technology, man can build a culture, "which is the field of reality populated by family organization or social and economic groups, classes, philosophy, science, the technique and all the products originating from these human activities" (1994, p. 23) [14].

Dusek stresses that a man subordinates completely the technology as a tool. Man designates the destination of this tool, which can lead to good or evil. The author mentions the hammer as an example, which hits a nail and even crushes a skull. However, when there is a technological system, the human being is within it, therefore has no control. "The technological systems that include advertising, propaganda and implementation of government can persuade, seduce or force users to accept them" (2006, p. 54) [16].

Dusek's idea about technological system corroborates with the proposition by Mitchell (2010) [17] for complex system, which does not have a central system of control because each part is interoperable. This idea brought by Mitchell ratifies Dusek's perspective because technology would be a complex 
system, as it would add several distinct elements, under which man can interact but never control completely. At the same time, technology would not represent the whole because it would only be a part of another system. This is also complex, and others elements would also be complex with several variants, as for instance the cultural factor.

Therefore, inserted in this context, technology has become a reflection of a drastic change. Drucker (2003, p. 5) [9] makes an analogy with a biological process to explain these changes: "The processes are not arranged from energy, the physical meaning of the word; they are arranged taking information as an origin". Although it is not the central purpose of this article to tackle with the science of data and information, it is worth making a brief addendum to situate these aspects in the discussion on innovation and communication, since they permeate various terms and ideas from this present work.

Cybernetics was the first line of thought to characterize the information as one of the pillars of contemporary society. Long before hearing about the information society as we know commonly nowadays, cybernetics proposed to develop a specific language and techniques. Those "enable us, in fact, so we can deal with the problem of control and communication in general, and to discover the repertoire of techniques and ideas appropriate to classify the specific manifestations under the rubric of certain concepts" (WIENER, 1954, p. 17) [18]. More than one branch focused on technology, Cybernetics believed that the information "designates the content of what we exchange with the external world to adjust ourselves to it, and that makes our adjustments be perceived in it" (p.18) [18].

Wiener's expression solidifies not only with what means "technology" in the philosophy of technology proposed by Dusek (2006) [16] and Vargas (1994) [14], but also with Drucker's proposition (2003). It reaffirms as well as the vision of communication as an exchange among agents as proposed by Wolton (2010) [13] and the relationship between innovation and communication of Giacomimi and Santos (2008) [12]. This is possible because the information is the raw material that moves people, machines and other systems, such as companies.

Concomitantly and in tune with surveys such as conducted by Wiener, other scholars like Claude Shannon (1948) [19] and Alan Turing (1950) [20], developed studies that were crucial to the development of machines, which mimic human behavior because they perform tasks formerly reserved for the brain (GLEICK, 2013) [21]. Another North American scientist may help us to understand why information is the basis of technology and how it interferes in the way humans deduce reality. When doing a study in the1950's on the functioning of the brain and computer, John Von Neumann concluded that the nervous system has the characteristics that "lead to a low level of arithmetic precision, but at a high level of logic reliability" (1958, p. 53) [22].

Wrapping up the addendum on the origins of the studies on information and endorsing the reasoning of Von Neumann, there is another proposition of Drucker. According to him, the high technology is "what the software used to call ratio "cognoscendi", the reason why we perceive and understand a phenomenon, instead of explaining why it arises and the cause of its existence" (2003, p. 6) [9]. Thus, we could think that man understands the technology by means of logical mental systems, since it performs associations among the facts around him. However, the man has difficulty in understanding and identifying the origins of all variables available in this regard.

Such mentality finds subsides in complex systems mentioned by Mitchell (2010) [17] and it can be found also in the very definitions of what is innovation in the wake of applied social sciences, such as communication. Frascatti's manual, one of the most rudimentary publications about innovation in the world, establishes some relationships among technology (especially information technology), research and development (R\&D) and the degree of innovation in studies in applied social sciences:

The development of software, by its nature, does not allow to discerning and identifying easily the element of P\&D where it does not exist. It is a part integral of many projects that are not part, themselves, of any element of R\&D. From these improvements, usually, an evolution arises rather than a revolution. We classify as $\mathrm{R} \& \mathrm{D}$, the transition to a more powerful version, an addition or a modification of a program or an existing system, if they incorporate the scientific progress and/or aids, which lead to an enrichment of knowledge (FRASCATTI MANUAL, 2002, p. 60) [23].

The mention of the overlaps between technology and the humanities in this manual derives from the concern that "social sciences and humanities are taken into account in the Manual, which incorporates the definition of P\&D: 'knowledge of man, culture and society"'(p. 62) [23].

Thus, journalism, being a part of social sciences, can generate innovation from the moment that modifies and renews technology (SCHUMPETER, 1961) [11]. When it has a meaning by the context used (DUSEK, 2006 [16]; VARGAS, 1994 [14]; LIMA, 2007 [15]). When it allows the exchange of information among agents (WOLTON, 2010 [13]; GIACOMINI, SANTOS, 2008 [12]), in a society dominated by computational machines (TURING, 1950 [20]; SHANNON, 1948 [19]; VON NEUMANN, 1958 [22]), from the Information (DRUCKER, 2003 [9]; GLEICK, 2013 [21]) in a system without central control (MITCHELL, 2010 [17]). Besides, the interaction among the parties evaluates innovation (WIENER, 1954 [18]).

\section{Crowdfunded Journalism}

After setting up similarities between innovation and communication, it is important to analyze an example that can be a point of intersection between them. The crowdfunded journalism is a recent practice in Brazil and the world. The concept of that, defined by Felinto is:

A process in which the public itself contributes to the financing of a project. Through websites on the Internet, producers announce their ideas (for a film, a work of art or product of any kind) and ask for financial aid to web surfers, who then make donations through the intermediation of those 
sites (2012, p. 140) [24].

This way of working finds scope in various elements of fandom culture, mentioned by Jenkins et al (2006) [25], which is based on the premise that the fan of a determined person, film, subject or another cultural element creates, distributes content and still collaborates, often financially, for a certain cause it deems fair. Jenkins reminds us that human behavior is not a technological invention, but this last influences it, since "these new technologies play a crucial role in enabling the changes described in this book" (JENKINS et al, 2006, p. 25).

This proposition by Jenkins also endorses Tapscott's ideas (1997) [26] regarding to the "Internet generation", a term created by him to refer to people born between 1977 and 1997. According to Tapscott, this group would have among its characteristics strong assimilation with technology, notably with the web, which brought many possibilities. One of them is that "allows people to create their own content, collaborate and build communities. Internet has become a selforganization tool " (1997, p. 29) [26].

Felinto explains that these changes brought about the creation of tools for the web, in which people can create and share content from external resources. That is, anyone who has interest in making a report, for example, and does not have the resources for it, can use Internet tools where it is possible to rally money through strangers' donations:

For the creators, crowdfunding opens up a whole range of new financing possibilities of their ideas. For the public, it provides a sense of participation never thought before. The fan feels as a co-creator, authentic collaborator of the productive process, able even to help set the destinations of works/products that he or she wonders (2012, p. 141) [24].

One aspect that stands out in this aspect is that the collaborative practice of gathering resources from the Internet for journalistic purposes is quite associated with the mentality of rupture with traditional media patterns. Xavier (2014) [27] and Nonato (2015) [28] emphasize that the crowdfunding mainly performed on blogs represents a freer journalism than the one practiced by the mass communication media, as they do not allow more work autonomy to the trader. The authors justify the existence of an undervaluing of the journalistic professional operation backed up by political and economic interests, that media vehicles traditionally maintain with advertisers and governments as a way to maintain the power hegemony.

In spite of not discarding the crowdfunding in other media, Xavier (2014) [27] and Nonato (2015) [28] emphasize its use on the internet because they believe that the World Wide Web allows greater freedom of operation by not having a centralizing power, which occurs with other vehicles. To Nonato (2015) [28], crowdfunding inn the web can even represent an alternative to the crisis affecting the sector.

Many articles and other works are published on the subject in journalism, however, do not join the discussion around whether the practice is being or not considered innovative. In this article, we believe that this question is very important, since innovation represents a way of breaking with the traditional practices and still exhibiting some evolution in the sector. The book "Conhecimento e inovação para a competitividade" ("Knowledge and innovation for competitiveness") is a World Bank publication that is a result of several studies and data collection made all over the planet. Created to help countries develop public policies and other instruments to foster innovation as a way of contributing to economic development, the work conceptualizes innovation as "the progress made on the border of global knowledge, but also as the first time it uses or adapts the technology to new contexts" (RODRIGUEZ et al, 2008, p 92) [29].

It is interesting to note the reference to the term adaptation, something applicable to the completion of the crowdfunding due to this, based on Internet platform, which a priori, it is a platform not designed with this purpose. As Jenkins (2006) [25] pointed out, it was not the technology that has created the collaborative and participatory approach to material production and distribution, although potentiated it. In addition, it is worth remembering that military intentions during the Cold War period developed the Internet. Therefore, totally at odds, with attributes such as the ones touted today.

The publication of the World Bank also made another relevant contribution when stated that innovation "is not limited in any way to the formal activities of research and development (...). On the contrary, the invention and the creation of knowledge can be produced by constant efforts to improve the production" (2008, p. 94) [29]. Relative to this aspect the report points out that there are different ways to innovate. We classify those ways according to some models.

Carvalho (2009) [30] classifies innovation in four types: Product, Process, Organizational, and Marketing. The first is the product type and would be the introduction of a new or significantly improved product or service. In this modality, we adopt new knowledge or new technologies based on new uses or new combinations of knowledge or existing technologies. The second, process innovation, concerns to the implementation of the new or significantly improved method of production or distribution. Whereas the third confines a new organizational method, a new negotiation practice, a new organization at the place of work or of external relations to organizational innovation. The fourth and last, marketing refers to changes in the product design or packaging, promotion, and pricing for strategic repositioning.

The crowdfunded journalism has a new process for the news production as its most striking feature, since it changes, at least in part, how to distribute the journalistic material and the form of financing the activity. As journalism is a service, the product of the relationship between company and consumer is not a physical commodity but public relevant information. Bearing in mind that crowdfunding changes the payment way of the service, so it is possible to evaluate it as a process innovation.

In this aspect, however, there are many questions. One is of ethical order, which does not comprise the classification of innovation, although deserves reflection. According to Adler (2015) [5], many citizens of the United States put into doubt the validity of crowdfunding when the organization that seeks 
resources for the achievement of a reportage is a profitable private company. He brings the example of the Huffington Post journal, which belongs to a group with revenues of 3.4 billion dollars and asked readers for money to perform a special report. According to Adler, the initiative aroused the indignation of non-governmental and other nonprofit organizations that seek in crowdfunding a way of making a freer and more investigative journalism.

Despite the criticism, the project raised a value greater than was originally envisaged. The company carried out the reportage, as announced. However, the amount invested did not overcome the initial projections, which generated more complaints from non-profit entities that rely on crowdfunding to survive. In addition, those organizations are a reminder that private companies profit on sales of advertising space with news sponsored by collective financing. However, the profit on advertising does not shared with the same people who helped to pay for the production of the reportage that brought the announcer to the vehicle of communication (Adler, 2015) [5].

This ambiguous behavior of private communication companies is not preventing the growth of the activity, which seems almost perpetual despite of the divergences between the public and ethical issues. In this matter, Adler (2015) [5] points out another delicate point of the relationship between communication media, journalists and readers. The question is to what extent the indirect crowdfunding financing is ethical, as the wages of many journalists originate from private companies while still getting income with the sale of advertising space and subscriptions.

If on the one hand this relationship jeopardizes the transparency of communications companies, on the other hand it generates a delicate situation with the reader who indirectly becomes the boss of the journalist, as there is a direct relationship of economic dependence. Adler (2015) [5] points out that a good part of non-governmental organizations does not establish a direct relationship between crowdfunding and subscriptions because the reports sponsored by them are generally divulgated without restriction, Being different from the traditional model of subscriptions in which only those who pay have access to the content.

Because it is not all about subscription, then how those who contributed with the crowdfunding could be evaluated? According to Adler, we can call the advocators "supporters" because they are citizens sharing the same ideas with journalists and seeking information that will be accessible only if they cooperate in some way.

Kaneya (2015) [4], however, brings another aspect that highlights a weakness and an opportunity of journalism in the face of the intensive use of technology in the making of reports, with innovations in the production and distribution of content. As many reportages supported by crowdfunding are investigative, including some institutions that get involved in making reportages only with this bias in the United States and in Brazil, a job search and data verification is necessary, requiring a large amount of time and knowledge from the journalist. Not by chance, some third sector entities is formed exclusively by programmers, systems analysts, and other information technology professionals who are dedicated to locating, collecting and treating data.

Called "civic hackers", many of these professionals are helping journalists to a great extent into creating stories that bring quality information to society, using the meta-data extracted from the Internet. Given that this practice is beneficial to society, it exposes the pillars of journalism as the need for a professional press to be the mediator between the company and the news. According to Kaneya Adler (2015) [4], even though the "civic hackers" themselves admit that they need a journalist to assist in various tasks, their possibility of operating as protagonists in the production of news is a sign of change. Such tasks could be the creation of a narrative that takes the matter to the attention of people in a believable and concise manner,

Far from being a threat, this situation can be a path for transformation in journalism. If innovation is a creative destruction, as Schumpeter stated (1961) [11], it is necessary to ensure that institutions and professionals renew themselves constantly, even more in a moment in which the journalism, as Nonato said (2015) [28], has been looking for ways to tackle employment crisis and prospects. Therefore, we can see crowdfunding as an innovation that came to integrate new skills to journalism, create new job opportunities, change and even break radically the flow of information with the structure of subordination between journalist and vehicles of communication.

By the way, those characteristics make it possible to classify crowdfunding as a radical innovation. According to the model by Davila, Epstein and Shelton (2007) [31], there is a level of novelty accomplished in innovation, which is incremental and radical. The factors that characterize the former are optimization and cumulative gains in efficiency. The latter, in turn, is a source of discontinuity as it breaks with the traditional patterns. In the case of crowdfunding, it concerns, for example, the emergence of a deregulation in the journalistic sector by breaking with the traditional logic of financing the journalistic activity and even with the production flow of news, previously fully focused on the figure of the journalist.

Precisely by breaking many structures of journalism, we can consider also the crowdfunding as a disruptive innovation. The modality proposed by Christensen (1997) [32] points to situations in which the new participants of the market, powered by simpler technological solutions, can advance ahead of companies that are the market leaders. While the new journalistic practice has not overcome the major media groups, the characteristics identified by the author as disruptive technology corroborate with many aspects of crowdfunding journalism.

In truth, the very fact that the novelty is not reaching a large consumer market and is restricting itself to certain niches currently is an indication that this scenario is all about rupture innovation.

According to Christensen: 
The technologies of rupture are usually marketable first in emerging and insignificant markets. The more profitable consumers from leading companies do not want to, and indeed, they cannot initially, use products offered by rupture technologies. In general, consumers of lower profitability in the market initially adopt a rupture technology. $(1997$, p. 26) [32].

Such notes corroborate a good part of the characteristics of crowdfunded journalism formation, such as the fact that the readers have a high degree of demand for a certain kind of reportage that discusses about a subject previously chosen. The ratio of people paying for news that could be for free or even the fact that this new journalistic practice currently is synonymous of quality and personalization in the face of massive content and pasteurized from traditional press.

\section{CONCLUSION}

It would be possible to extend the analysis for the application of theoretical concepts of innovation in the light of crowdfunded journalism for many other lines but the analysis performed has already proved that the classification for what is innovative is undisputed to this new journalistic practice. More than a new term, this observation proves that journalism is under a process of change from human practices and technological development.

Just as we should not deny the human fact as the trigger of practices, such as collaboration and sharing, it is highly recommended to realize how human being and vice-versa shape technology. In this two-way relationship, man and machine alternate in the task of creating new communication mechanisms. Thus, it is important that humans take control of machinery operation systems to promote the changes that innovation requires. Without their will, innovation in machines is an ongoing and one-way ticket process.

\section{REFERENCES}

[1] M. Castells. "A sociedade em rede". São Paulo: Paz e Terra, 2000, pp. 54-92.

[2] P. Serra; S. Sá; W. Souza Filho (Orgs). "A televisão ubíqua”. Covilhã: LabCom, 2015, pp. 11-39.

[3] J. Canavilhas; I. Satuf. "Jornalismo para dispositivos móveis: produção, distribuição e consume". Covilhã: LabCom, 2015, pp. 24-41.

[4] R. Kaneya, "Hackers do bem". Revista de Jornalismo ESPM, vol. 4, n. 12, pp. 20-23, Jan. Fev. Mar. 2015.

[5] B. Adler. 'O povo que pague". Revista de Jornalismo ESPM, vol.4, n. 12, pp. 64-67, Jan. Fev. Mar. 2015

[6] R. C. Alves. "Jornalismo digital: Dez anos de web... e a revolução continua”. Comunicação e Sociedade, vol. 9, pp. 93-102, 2006.

[7] T. E. Gerhardt; D. T. Silveira. "Métodos de pesquisa". Porto Alegre: Editora da UFRGS, 2009, pp. 34-38.

[8] L. Santaella. "Comunicação e pesquisa: projetos para mestrado e doutorado". São Paulo: Hacker Editores, 2001, p. 97-98.

[9] P. Drucker. "Inovação e espírito empreendedor (entrepreneurship)". São Paulo: Pioneira Thomson, 2003. pp. 15-85

[10] S. Meira. "Novos negócios inovadores de crescimento empreendedor no Brasil". Rio de Janeiro: Casa da Palavra, 2013, pp. 86-131.

[11] J. Schumpeter. "Capitalismo, Socialismo e Democracia". Rio de Janeiro: Editora Fundo de Cultura, 1961, pp. 54-61.

[12] G. Giacomini Filho; R. E. Santos. "Convergências conceituais e teóricas entre comunicação e inovação". In: Comunicação e inovação: reflexões contemporâneas. M. P. Caprino (Org.). São Paulo: Paulus, 2008, pp. 4754.

[13] D. Wolton. Informar não é comunicar. Porto Alegre: Editora Sulina, 2010, pp. 87-98.

[14] M. Vargas. Para uma filosofia da tecnologia. São Paulo: Editora Alfa Ômega, 1994, 154-190.

[15] J. E. R. Lima (2007). Considerações sobre filosofia da tecnologia. Paper apresentado na I Conferência Brasileira de Comunicação e Tecnologias Digitais da Universidade Metodista de São Paulo. [Online]. Available: https://goo.gl/A6Uiz3

[16] V. Dusek. Filosofia da tecnologia. São Paulo: Edições Loyola, 2006, pp. 98-115.

[17] M. Mitchell. Complexity: an introduction. Nova York: Oxford University Press, 2010, pp. 201-210.

[18] N. Wiener. The human use of human beings: Cybernetics and society. Perseus Books Group, 1954, pp. 15-28.

[19] C. Shannon. "A Mathematical Theory of Communication". Bell System Technical Journal, vol. 27, pp. 379-423, July, October, 1948.

[20] A. M. Turing. "Computing Machinery and Intelligence". Mind, New Series, vol. 59, n.236, p. 433-460, 1950.

[21] J. Gleick. The Information: A History, a Theory, a Flood. New York: Pantheon Books, 2011, pp. 351-389.

[22] J. V. Neumann. The Computer and the Brain. New Haven/London: Yale Univesity Press 1958, pp. 48-91.

[23] Frascati Manual, Organisation for Economic Co-operation and Development, Geneve, Switzerland, pp. 58-76.

[24] E. Felinto. "Crowdfunding: entre as multidões e as corporações". Revista Comunicação, Mídia e Consumo, v. 9, n. 26, p. 137-150, nov. 2012.

[25] H. Jenkins. Culture of convergence. New York University Press, 2006, pp. $22-61$

[26] D. Tapscott. Grown Up Digital: How the Net Generation Is Changing Your World. New York: McGraw Hill, 1997, pp. 20-46.

[27] A. C. R. Xavier. Alternativas para o financiamento do jornalismo: Crowndfunding e a campanha Reportagem Pública. In: $12^{\circ}$ Encontro Nacional de Pesquisadores em Jornalismo. Anais... Santa Cruz do Sul: SBPJor, 2014, p. 1-17.

[28] C. Nonato. "Blogs, colaborativismo e crowdfunding: novos arranjos para o livre exercício do jornalismo e a prática da cidadania". Revista Alterjor, v. 2, n. 12, p. 1-14, 2015.

[29] A. Rodriguez; C. Dahlman; J. Salmi (2008). Knowledge and innovation for competitiveness in Brazil. Washington, DC: The International Bank for Reconstruction and Development; World Bank. [Online]. Available: https://goo.gl/YscSW6.

[30] M. Carvalho. Inovação: Estratégias e comunidades de conhecimento. São Paulo: Atlas, 2009, pp. 75-110.

[31] T. Davila; M. Epstein; R. Shelton. As regras da inovação: Como gerenciar, como medir e como lucrar. Porto Alegre: Bookman, 2007, pp. 86-91.

[32] C. Christensen. "The innovator's dilemma. When New Technologies Cause Great Firms to Fail". Harvard Business Review Press, 1997, pp. 25-56.

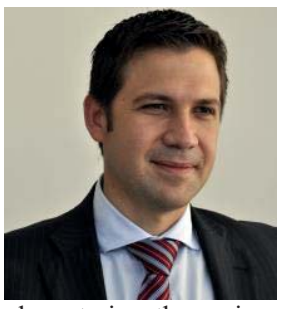

\section{Lucas V. de Araújo}

Degree in Journalism (1999), Master in Brazilian and Portuguese Literature (2008) and holds a doctorate in Communication from the Universidade Metodista de São Paulo (2015). Currently conducts a research that evaluates the communication innovation ecosystem in Brazil. Currently conducts a research that evaluates the communication innovation ecosystem in Brazil, identifying and charactering the main communication innovation movements in the country within the ecosystem.

He has worked in several TV stations in Brazil as an editor, reporter and Journalism Manager at Rede Globo, Rede Record and Rede Bandeirantes. He also worked as a Professor with undergraduate and graduate degrees in Journalism, Marketing and Advertising. Has a book published about the writer Domingos Pellegrini from Paraná, and articles on Data Journalism, Deep Web, new media and ethics in the use of data. 